\title{
Sesambein på vandring
}
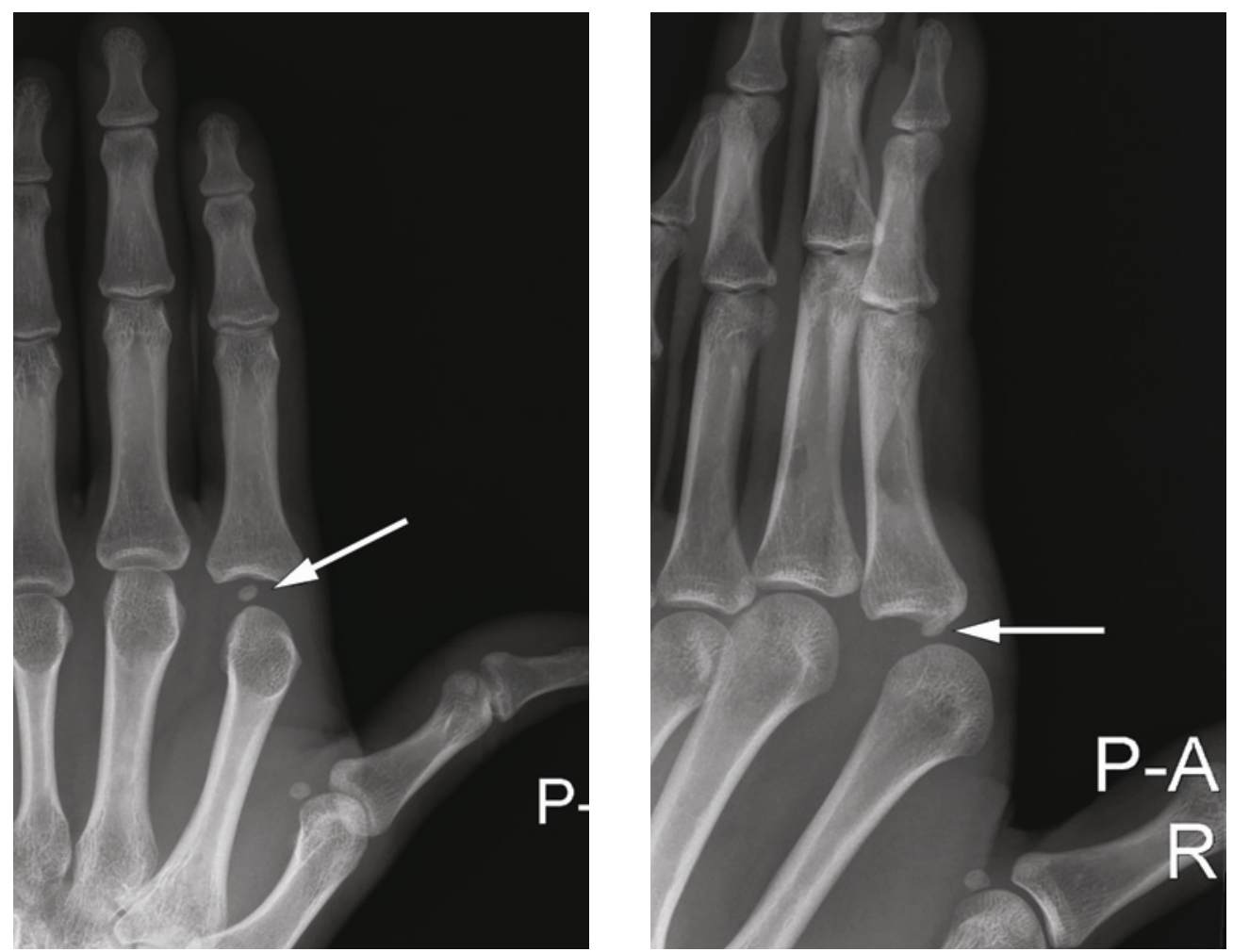

En jente i tenårene hadde støtt sammen med en motspiller under en håndballkamp og fått metakarpofalangealleddet (MCP-leddet) i høyre pekefinger ut av ledd. Fingeren ble forsøkt grovreponert på stedet. Ved undersøkelse på kirurgisk poliklinikk sto fingeren ulnardeviert og moderat dorsalflektert. Stillingen ga mistanke om en ikke-reponerbar luksasjon. Slike luksasjoner kalles komplekse, i motsetning til enkle luksasjoner, som lar seg reponere ved vanlig lukket teknikk (1).

Den volare platen, en bindevevsplate som forsterker leddkapselen, bidrar til volar stabilitet ved metakarpofalangealleddet. Hos de fleste er det $\mathrm{i}$ enkelte av disse leddene «innebygd» sesambein i volarplaten. I en studie basert på røntgenbilder av 442 personer fra middelhavsland hadde $99,5 \%$ sesambein ved første metakarpofalangealledd, nest vanligst var det ved annet metakarpofalangealledd $(42,3 \%)$, dernest ved femte $(41,1 \%)$ (2). Røntgenbildene av pasientens hånd viste et sesambein i leddspalten (pil), et patognomonisk tegn på at volarplaten, som sesambeinet er festet $\mathrm{i}$, er rumpert og ligger låst mellom leddflatene. I slike tilfeller lukserer i tillegg caput metacarpale palmart og blir låst mellom sener, muskler og ligamenter. Dette er en kompleks luksasjon, som forekommer forholdsvis sjelden.
Som anbefalt i litteraturen ble leddet først forsøkt reponert ved å hyperekstendere i metakarpofalangealleddet og legge et dorsalt trykk mot grunnfalangen (1). Som forventet lot det seg ikke gjøre. Det ble nødvendig med åpen operasjon for å få reponert volarplaten og leddet. Volarplaten var rumpert i proksimale ende og ble suturert. Pasienten fikk deretter skinnebehandling i seks uker. Ved kontroll etter tre måneder hadde hun god bevegelighet, men noe nedsatt kraft for fleksjon, i aktuelle metakarpofalangealledd.

Pasienten og hennes pårørende har gitt samtykke til at artikkelen blir publisert.

\section{Sverre Myren*}

sverre@myren.nu

Avdeling for nevrologi og klinisk nevrofysiologi St. Olavs hospital

\section{Kirsten Larsen Grønhaug*}

Ortopedisk avdeling

Sykehuset Østfold

\section{Bjørn Svarva}

Avdeling for bildediagnostikk Sykehuset Levanger

* Tidligere arbeidssted:

Ortopedisk avdeling, Sykehuset Levanger
Sverre Myren (f. 1986) er lege i spesialisering i nevrologi.

Forfatter har fylt ut ICMJE-skjemaet og oppgir ingen interessekonflikter.

Kirsten Larsen Grønhaug (f. 1977) er overlege i ortopedi.

Forfatter har fylt ut ICMJE-skjemaet og oppgir ingen interessekonflikter.

Bjørn Svarva (f. 1980) er lege i spesialisering i radiologi.

Forfatter har fylt ut ICMJE-skjemaet og oppgir ingen interessekonflikter.

\section{Litteratur}

1. Lattanza LL, Choi PD. Intraarticular injuries of the metacarpophalangeal and carpometacarpal joints. I: Berger RA, Weiss APC, red. Hand surgery. Philadelphia, PA: Lippincott Williams \& Wilkins, 2004. www.msdlatinamerica.com/ebooks/HandSurgery/ sid201702.html (3.1.2014).

2. Amar E, Rozenblat Y, Chechik O. Sesamoid and accessory bones of the hand - an epidemiologic survey in a Mediterranean population. Clin Anat $2011 ; 24: 183-7$ 